\title{
Merkezi Bir Kompozit Tasarım Kullanılarak Karboksimetil Selüloz Temelli Hidrojelin Şişme Oranının Belirlenmesi
}

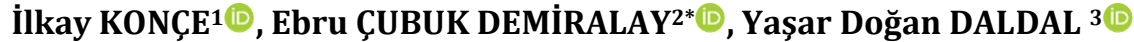 \\ ${ }^{1}$ Süleyman Demirel Üniversitesi, Fen Edebiyat Fakültesi, Kimya Bölümü, 32200, Isparta, Türkiye \\ ${ }^{2}$ Süleyman Demirel Üniversitesi, Eczacıllk Fakültesi, Temel Eczacıllk Bilimleri Bölümü, 32200, Isparta, Türkiye \\ ${ }^{3}$ Kahramanmaraş İstiklal Üniversitesi, Elbistan Sağlık Hizmetleri Meslek Yüksek Okulu, 46300, Kahramanmaraş, \\ Türkiye
}

(Alınış / Received: 25.08.2021, Kabul / Accepted: 29.11.2021, Online Yayınlanma / Published Online: 25.12.2021)

Anahtar Kelimeler

Hidrojel,

Şişme davranışı,

Optimizasyon,

Merkezi kompozit dizayn
Özet: Bu çalışmada, çapraz bağlayıcı olarak sitrik asit kullanılarak karboksimetil selüloz temelli hidrojel sentezlenmesi ve su tutma kabiliyetinin değerlendirilmesi amaçlanmıştır. Maksimum su emme kapasitesine sahip hidrojelin sentezi için en uygun miktarları belirlemek ve hidrojelin sentezinde yer alan faktörlerin ana etkisini ve etkileşim etkisini incelemek için merkezi kompozit tasarım metodu kullanılmıştır. Polimer bileşimi, sodyum karboksimetil selüloz, sitrik asit ve polietilen glikol 6000/10000 konsantrasyonu (\%w/v) gibi ana faktörlerin şişme hızı üzerindeki etkisi değerlendirilmiștir. Ürün bileșeninin optimizasyonu ve tüm verilerin istatistiksel olarak değerlendirilmesi Minitab 17 İstatistik Yazılımı programı ile yapılmıştır. Elde edilen sonuçlar değerlendirildiğinde süper emici hidrojelin optimum koşullar altında üretildiğini göstermiştir.

\section{Determination of Swelling Ratio on Carboxymethyl Cellulose-Based Hydrogel Using A Central Composite Design}

Keywords

Hydrogel,

Swelling behavior,

Optimization,

Central composite design

\begin{abstract}
This study, it was aimed to synthesize carboxymethyl cellulose-based hydrogel using citric acid as a cross linker and to evaluate its water-holding ability. The central composite design method was used to determine the optimal amounts for the synthesis of the hydrogel with its maximum water absorption capacity and to examine the main effect and interaction effect of the factors involved in the synthesis of the hydrogel. The effect of main factors such as polymer composition, sodium carboxymethyl cellulose, citric acid, and polyethylene glycol concentration $(\mathrm{w} / \mathrm{v} \%)$ on swelling rate was evaluated. Optimization of the product component and statistical evaluation of all data were carried out with the Minitab Statistical Software program. When the results were evaluated, it showed that the super absorbent hydrogel was produced under optimum conditions.
\end{abstract}

\section{Giriș}

Hidrojeller, fiziksel, kimyasal veya ışıma çapraz bağlama ile hazırlanabilen, üç boyutlu polimerik ağ yapılarıdır. Bu yapılar, kendisinden onlarca kat fazla ağırlıktaki suyu bünyesinde tutmasının yanı sıra, çözünmeme özelliğine de sahiptirler. Yapılarındaki gözenekler, bileşiklerin jel matrisine yüklenmesini ve ardından da jel ağı boyunca, farklı büyüklükteki moleküllerin difüzyon katsayısına bağlı bir oranda salınımına olanak sağlar. Bu özellikler, belirlenen etki alanına göre, belirli bir oranda terapötik yani tedavi edici maddelerin etkin taşıyıcıları yapar $[1,2]$.

Polisakkarit temelli hidrojeller, akıllı malzemeler gibi davranırlar ve çeşitli uygulamalarda yaygın şekilde kullanılabilirler. Selüloz, geleneksel malzemelere alternatif, çevre dostu bir polisakkarittir ve birçok uygulamada genişçe kullanım alanı vardır. Günümüzde selüloz türevlerine dayalı hidrojeller, ilaç endüstrisi ve tarımda büyük bir popülerlik kazanmıștır [3]. Selüloz, yeryüzünde bol miktarda bulunan karbonhidrat polimeridir. Doğal bir polimer olan selüloz, sentetik polimerlerde olduğu gibi basit ve tekrarlanan birimlerden oluşur. Ayrıca biyouyumludur, biyolojik olarak parçalanabilir, toksik değildir ve ucuzdur. Selüloz ve türevleri, çok sayıda hidroksil grubuna sahip olduklarından, hidrojellerin hazırlanmasında kullanılırlar. Bunlar içerisinde selüloz eterleri, iki ana selüloz türevini kapsamaktadır. Selüloz eterleri, genellikle 
hidrofiliktir ve suya maruz kaldıklarında hidrojele dönüşüler. İyi çözünürlük, yüksek kimyasal direnç, toksik olmama, düşük maliyet ve doğal malzeme olma gibi özelliklere sahip selüloz eterleri, yapı malzemelerinde, gıda, ilaç ve kozmetik formülasyonlarında, stabilizatör ve ana bileşen olarak kullanılır. En sık kullanılan selüloz eterleri, metil selüloz (MC), etil selüloz (EC), hidroksietil selüloz (HEC), karboksimetil selüloz (CMC), sodyum karboksimetil selüloz (NaCMC), hidroksipropil selüloz (HPC) ve hidroksipropilmetil selülozdur (HPMC) [4].

Yukarıda belirtilen selüloz eterleri arasında, sadece sodyum karboksimetil selüloz (NaCMC) bir polielektrolittir ve bu nedenle, $\mathrm{pH}$ ve iyonik mukavemet değişkenliğine duyarlılık gösteren akıllı bir selüloz türevidir. Selüloz temelli bir hidrojelde, sodyum karboksimetil selülozun varlığı, şişme kabiliyeti sağlamaktadır. Sodyum karboksimetil selülozun polielektrolit doğası, süper absorban hidrojellerin geliştirilmesi için idealdir [5]. NaCMC yüksek biyouyumluluğu, biyolojik olarak bozunabilirliği ve düşük immünojenisitesi sayesinde, belirlenen bölgeye özgü veya kontrollü ilaç salınımının taşıyıcı matrisleri olarak, farmasötik ürünlerde kullanım için çok önemli bir potansiyele sahiptir. Yaplan inceleme neticesinde NaCMC hidrojellerinin, mükemmel şişme ve viskodinamik elastikiyet sergilediği tespit edilmiştir. Birçok araştırmacı, çoğunlukla fiziksel veya kimyasal çapraz bağlama ajanları kullanarak NaCMC temelli hidrojeller hazırlamıștır [6-9]. NaCMC temelli hidrojellerin hazırlanması için kullanılan çapraz bağlama ajanlarının birçoğunun, toksik özellikte olduğu bilinmektedir. Bu nedenle, toksik çapraz bağlama ajanlarının yerine polikarboksilik asitler, NaCMC temelli hidrojellerin hazırlanması için hem toksik olmayan hem de ucuz bir alternatif olarak kullanılmıştır. Son zamanlarda, çeşitli selüloz türev sistemlerinde çapraz bağlama maddesi olarak sitrik asit kullanılmış ve literatürde selüloz veya selüloz türevi polimerlerin sitrik asit ile çapraz bağlanma reaksiyonunu açıklamak için farklı mekanizmalar önerilmiştir [10-12].

Polietilen glikol (PEG), hidrojel üretimi ve uygulamasında belirgin avantaj sağlayan hidrofilik monomer olarak bilinir ancak aynı zamanda yapısındaki etilen gruplarından dolayı bir miktar hidrofobik özelliğe de sahiptir [13]. Bu özelliği sayesinde hidrofobik ilaç moleküllerini hapsetme yeteneğine sahiptir. Suda ve ayrıca birçok organik çözücüde çözünen bir polieterdir. PEG toksik değildir, bu nedenle biyolojik uygulamalar için idealdir. Yapısında bulunan hidroksil grupları, farklı fonksiyonel gruplarla, kolaylıkla reaksiyona girebilir [12]. PEG, belirli formülasyonlara eklendikten sonra, formülasyonun yavaş salınmasına izin verir, böylece kontrollü salınım sağlar. Ayrıca $A B D$ Gıda ve İlaç
Dairesi (FDA) tarafından insanlarda kullanımı için onaylanmış bir kimyasal grubudur [14].

Hidrofobik bileşik ile hidrofilik polimerin birbirini dışlaması nedeniyle, hidrofilik hidrojellere hidrofobik bileșiği yüklemek ve salınımlarını kontrol etmek zordur. Bu sebeple, hidrofilik olan CMC temelli hidrojellere, hidrofilik bileşiklerin yüklenmesi tercih edilir. $\mathrm{Bu}$ tip hazırlanacak olan hidrojellere, hidrofobik bileşikler yüklenmek istenildiğinde ise, çözünürlüğü artırıcı siklodekstrin ve türevleri polimer çözeltilerine ilave edilir. Siklodekstrinler, toksik olmayan $\alpha$-D-gluko piranoz monomerlerinden oluşan siklikoligo-sakkaritlerdir. Siklodekstrinler, hidrofobik bileşik moleküllerinin suda çözünürlüğünün artırılması ve inklüzyon komplekslerinin oluşturulması için farmasötik alanda yaygın kullanım alanına sahiptir [15-17]. Siklodekstrinler suda çözünebilme özelliğine sahip iken, siklodekstrin kompleksleri oldukça kararlı yapılar olup, sulu çözeltilerde çözünürlükleri azalmakta ve böylece kristalizasyonla ortamdan kolaylıkla ayrılmaktadırlar. 2-hidroksipropil- $\beta$ siklodekstrin (HP $\beta C D), \beta$-siklodekstrin türevidir ve suda çözünürlüğü az olan konuk moleküllerle inklüzyon kompleksi oluşturmak amacıyla, yaygın bir kullanım alanına sahiptir. 2-HPßCD, ilaç endüstrisinde en çok kullanılan türevlerdir ve toksisiteleri düşük, çözünürlükleri yüksektir. Ayrıca, oral ve parental uygulamalar için uygundur [16].

Şişme, polimerik ağ yapılarının karakteristik bir özelliğidir. Bu ağ yapısı, çapraz bağlanma miktarına göre bozulmadan yüksek miktarda sıvı absorbe edebilir. Şişme, polimer çözeltisindeki polimer zincirleri ile çözücü arasındaki etkileşimle gerçekleşen bir durumdur. Hidrojellerin karakterizasyonu için, en temel yöntemlerden birisi şişme davranıșının belirlenmesidir. Denge șişme değerleri, hidrojelin karakterizasyonu ve endüstriyel kullanımı için çok önemlidir. Çapraz bağlı polimerler uygun çözücü ortamında, çözücünün polimerik yapıya girmesi ile şişmeye başlar. Belirli bir süre sonra çözücünün jele girme hızı ile jelden salınım hızı birbirine eşit olur. $\mathrm{Bu}$ durum, en büyük șişme değerine ulaşıldığı denge durumudur. Su içeriklerine göre hidrojeller; doğal, düşük şişme dereceli (20$50 \%)$, orta şişme dereceli (50-90\%), yüksek şişme dereceli (90-99,5\%) ve süper absorbent (>99,5\%) hidrojeller olarak sınıflandırılmaktadır [18].

Jelin yapısındaki hidrofilik gruplar, su ile etkileștiğinde hidrojen bağları oluştururlar. Bu gruplar ile, jelin kütlesi ve hacmi artarak şişmeye başlar. Jel yapısında hidrofilik grup sayısı arttıkça şişme de artar [19]. Şişme derecesi (\%), Eşitlik 1 ile hesaplanır.

$$
\% \text { Şişme }=\frac{W_{t}-W_{0}}{W_{0}} \times 100
$$


Eşitlikteki $\mathrm{W}_{\mathrm{t}}$; $\mathrm{t}$ süre sonra şişmiş jel kütlesini, $\mathrm{W}_{0}$ : başlangıçtaki kuru jel kütlesini ifade etmektedir.

Hazırlanan hidrojelde temel bileșen miktarının belirlenmesi ve maksimum şişme kapasitesine ulaşmak amacıyla çoğunlukla deneme yanılma yöntemi kullanılmaktadır. $\mathrm{Bu}$ tip çalışmalar, kullanılan kimyasalların pahalı, uygulanan yöntemin de çok zaman alması nedeniyle, oldukça maliyetlidir. Ayrıca, deneme yanılma yoluyla belirlenen optimum miktarların en iyi şişme sonucunu verebileceği de kesin değildir. $\mathrm{Bu}$ nedenle, deney sonuçlarını etkileyebilecek faktörlerin belirlenmesi, tasarlanması ve en az sayıda deneyle optimum miktarların belirlenmesi için planlanan ve sonuçların istatiksel analizle belirlenmesini sağlayan deneysel tasarım metotları, günümüzde sıklıkla kullanılmaktadır. Deneyde, etkinliği belirli değişkenler belirlendikten sonra bir tasarım seçimi yapılmalıdır.

Bu çalıșmada, seçilen her bir faktörün yüksek, düșük, orta ve alfa olarak bilinen seviyelerde bulunduğu bir merkezi kompozit deney tasarımı oluşturulmuştur. Merkezi kompozit tasarım deneylerinin analizinde, varyans analizi (ANOVA) ve regresyon analizi kullanılmaktadır. Varyans analizi, hangi proses üzerinde hangi faktörlerin ne derecede önemli olduklarını istatistiksel olarak açıklamaktadır [20]. Regresyon analizi, sebep (bağımsız girdi değişkeni) ve sonuç (bağımlı çıktı değişkeni) arasında net bir matematiksel ilişkinin varlığını tespit etmek için kullanılır [21].

Sunulan bu çalışmada merkezi kompozit tasarım ile NaCMC, sitrik asit ve polietilen glikol 6000/10000 değişkenlerinin miktarlarına göre maksimum su emme kapasitesine sahip karboksimetil selüloz temelli hidrojelin sentezi amaçlanmıştır. Ayrıca bu çalışmada, hidrojelin sentezinde yer alan değişkenlerin ana etkisi ve birbirleriyle olan etkileşimlerin etkisi de incelenmiştir.

\section{Materyal ve Metot}

\subsection{Deneysel çalışmada kullanılan kimyasal maddeler ve cihazlar}

Hidrojellerin sentezlenmesi için kullanılan kimyasal maddeler ve cihazlar, Tablo 1 ve Tablo 2'de verilmiştir.

Tablo 1. Hidrojellerin sentezinde ve şişme testi için kullanılan kimyasal maddeler ve özellikleri

\begin{tabular}{cccc}
\hline Kimyasalın Adı & $\begin{array}{c}\text { Molekül } \\
\text { Kütlesi }\end{array}$ & Saflığı & $\begin{array}{c}\text { Temin } \\
\text { Edilen } \\
\text { Firma Adı }\end{array}$ \\
\hline Karboksimetil & 262,19 & $\geq 99,5 \%$ & $\begin{array}{c}\text { Acros } \\
\text { selüloz sodyum }\end{array}$ \\
tuzu & $\begin{array}{c}\mathrm{DS}=0.7) \\
\text { - }\end{array}$ & & Organics \\
$2-$ & 1180,05 & $97,0 \%$ & Acros \\
hidroksipropil- & $\mathrm{g} / \mathrm{mol}$ & & Organics \\
$\beta$-siklodekstrin & & &
\end{tabular}

\begin{tabular}{|c|c|c|c|}
\hline $\begin{array}{l}\text { Polietilen glikol- } \\
\quad 6000\end{array}$ & $\begin{array}{l}5400 \\
\mathrm{~g} / \mathrm{mol}\end{array}$ & $\geq 99,0 \%$ & Merck \\
\hline $\begin{array}{l}\text { Polietilen glikol - } \\
\quad 10000\end{array}$ & $\begin{array}{l}10000 \\
\mathrm{~g} / \mathrm{mol}\end{array}$ & $\geq 99,0 \%$ & $\begin{array}{l}\text { Honeywell / } \\
\text { Fluka }\end{array}$ \\
\hline Sitrik asit & $\begin{array}{l}192,12 \\
\mathrm{~g} / \mathrm{mol}\end{array}$ & $\geq 99,5 \%$ & $\begin{array}{l}\text { Riedel de } \\
\text { Haën }\end{array}$ \\
\hline Sodyum asetat & $\begin{array}{l}82,03 \\
\mathrm{~g} / \mathrm{mol}\end{array}$ & $99,0 \%$ & Panreac \\
\hline Asetik asit & $\begin{array}{l}60,05 \\
\mathrm{~g} / \mathrm{mol}\end{array}$ & $100 \%$ & $\begin{array}{l}\text { Sigma- } \\
\text { Aldrich }\end{array}$ \\
\hline $\begin{array}{l}\text { Sodyum } \\
\text { karbonat }\end{array}$ & $\begin{array}{l}105,99 \\
\mathrm{~g} / \mathrm{mol}\end{array}$ & $\geq 99,0 \%$ & Tekkim \\
\hline $\begin{array}{c}\text { Sodyum } \\
\text { bikarbonat }\end{array}$ & $\begin{array}{l}84,01 \\
\mathrm{~g} / \mathrm{mol}\end{array}$ & $\geq 99,0 \%$ & Tekkim \\
\hline
\end{tabular}

Tablo 2. Hidrojellerin sentezinde kullanılan cihazlar

\begin{tabular}{ll}
\hline Cihazın Adı & Firma /Model Adı \\
\hline Hassas Analitik Terazi & Precisa LS 320A SCS \\
Saf Su Cihazı & Millipore Direct Q3-UV \\
Vakum Etüvü & CLS CLVO-27T \\
Isıtıcılı Manyetik Karıștırıcı & JSR JSHS-18 \\
Mikro Pipet & Nichipet EXII Vol. 1000- \\
& $5000 \mu \mathrm{L}$ \\
pH metre & Mettler Toledo S 220 seven \\
& compact \\
\hline
\end{tabular}

\section{2. Çapraz bağlı hidrojelin hazırlanması}

Hidrojel $10 \mathrm{~mL}$ polimer çözeltisi ile hazırlanmıştır. $\mathrm{Bu}$ çalışmada, deney sonuçlarını etkileyebilecek faktörler belirlenerek (NaCMC, sitrik asit, PEG-6000/PEG10000) seçilen deneysel tasarım için, 6 tekrar deneyi ile birlikte 20 adet deney yapılmıștır. NaCMC, sitrik asit, PEG-6000/PEG-10000'den olușan polimer karıșımında, bileșiklerin hacimde ağırlıkça yüzdeleri kullanılmıştır. Bu çözelti ortamına katılacak olan HP $\beta C D$ miktarı, monomer miktarı toplamda 0,350 gramda sabit tutulduğunda, NaCMC'nin miktarına göre değişiklik göstermektedir. Bunun için, her bir deneyde öncelikle tartılması gereken NaCMC, $10 \mathrm{~mL}$ saf suda manyetik karıştırıcı yardımıyla iyice çözülmüştür. Sonra, tasarımdaki miktarlar kullanılarak, PEG 6000, HPßCD ve sitrik asit sırasıyla çözelti ortamına ilave edilmiş ve hava kabarcığ kalmayıncaya kadar manyetik karıștırıcı ile oda sıcaklığında 300 rpm'de karıștırılmıştır. Karıșım, silikon kaba ilave edilmiş ve bir gece boyunca buzdolabında $+4^{\circ} \mathrm{C}$ 'de bekletilmiştir. Silikon kaptaki hidrojeller, vakum etüvü kullanılarak kurutulmuştur. Kurutma işlemi, sırasıyla; $50^{\circ} \mathrm{C}$ ve $25 \mathrm{kPa}$ vakum sınırında 80 dakika, sitrik asidin siklik anhidrite dönüşmesi için $90^{\circ} \mathrm{C}$ ve $25 \mathrm{kPa}$ vakum sınırında 5 dakikada gerçekleștirilmiștir. Polimerik çözeltinin oluşumunda, reaksiyona girmeyen reaktiflerin uzaklaştırılması için, çözelti $+4{ }^{\circ} \mathrm{C}$ 'de 4 saat bekletilmiştir. $\mathrm{Bu}$ hidrojeller önce oda sıcaklığında, daha sonra da $40^{\circ} \mathrm{C}$ vakum etüvünde sabit tartıma gelene kadar kurutulmuştur. Sentezlenen hidrojeller, şişme testi yapılıncaya kadar, hidrojellerin hava ile olan etkileşiminin önlenmesi amacıyla, cam şişelere konulup vakum desikatöründe saklanmıștır. $\mathrm{Bu}$ işlemlerin aynısı, PEG-10000 içinde üç tekrarlı olarak gerçekleştirilmiştir. 


\subsection{Merkezi kompozit tasarım tekniğiyle optimum miktarların belirlenmesi}

Daha az sayıda deneyle sadece etkisi incelenmek istenen faktörlerin cevap değeri üzerindeki etkileri, tasarımın ön gördüğü deneysel koşullar ile belirlenir. Hidrojelin hazırlanması aşamasında, reaksiyon sıcaklığı ve süresi sabit tutulduğunda, en önemli faktörler NaCMC, sitrik asit, PEG-6000/PEG10000'dir.

Hidrojelin hazırlanması aşamasında reaksiyon sıcaklığı ve süresi sabit tutularak maksimum şişme derecesine, NaCMC, sitrik asit, PEG-6000/PEG10000'nin birleştirilmiş etkisi, merkezi kompozit tasarım metodu ile incelenmiştir. Seçilen üç parametre için oluşturulan merkezi kompozit dizayn, merkez noktasında yapılan altı tekrarla birlikte, 20 farklı deney gerektirmektedir. Seçilen parametrelerin alt, orta, üst ve alfa $(\alpha)$ sinırlarl, Tablo 3'de verilmiştir.

Tablo 3. Merkezi kompozit dizayn metodunda kullanılan parametrelerin alt, orta, üst ve alfa $(\alpha)$ sinırları

\begin{tabular}{cccccc}
\hline $\begin{array}{c}\text { Bağımsız } \\
\text { parametreler }\end{array}$ & $(-\alpha)$ & $\begin{array}{c}\text { Alt } \\
\text { nokta } \\
(-)\end{array}$ & $\begin{array}{c}\text { Orta } \\
\text { nokta } \\
(0)\end{array}$ & $\begin{array}{c}\text { Üst } \\
\text { nokta } \\
(+)\end{array}$ & $(+\alpha)$ \\
\hline $\begin{array}{c}\text { NaCMC } \\
(\% \mathrm{w} / \mathrm{v})\end{array}$ & 0.173 & 0.200 & 0.240 & 0.280 & 0.307 \\
$\begin{array}{c}\text { Sitrik Asit } \\
(\% \mathrm{w} / \mathrm{v}) \\
\text { PEG- }\end{array}$ & 0.050 & 0.060 & 0.075 & 0.090 & 0.100 \\
$\begin{array}{c}\text { (000/PEG- } \\
10000\end{array}$ & 0.018 & 0.020 & 0.023 & 0.025 & 0.027 \\
$(\% \mathrm{w} / \mathrm{v})$ & & & & & \\
\hline
\end{tabular}

Parametre olarak PEG 6000'in kullanıldığı dizayndaki aynı koşullar, PEG-10000 için de uygulanmıştır.

$\mathrm{Bu}$ çalışmada, seçilen deneysel tasarım için 6 tekrar deneyi ile birlikte 20 adet deney yapılmış ve bu tasarımdaki bileşikler kullanılarak, sabit sıcaklık, vakum sinırı ve sürede, HP $\beta C D-C M C$ hidrojeli sentezlenmiștir (Tablo 4). Monomer miktarı toplamda 0,350 gramda sabit tutulduğunda, çözelti ortamına katılacak olan HP $\beta C D$ miktarı, NaCMC'nin miktarına göre değişiklik göstermiştir. Minitab 17 programı [22] kullanılarak oluşturulan merkezi kompozit tasarım, Tablo 4'de verilmiștir. Yapılan her bir deneysel çalışma, üç tekrarlı olarak gerçekleştirilmiştir.

Tablo 4. Merkezi kompozit tasarım verileri

\begin{tabular}{cccc}
\hline $\begin{array}{c}\text { Deney } \\
\text { No }\end{array}$ & $\begin{array}{c}\text { NaCMC } \\
(\% \mathrm{w} / \mathrm{v})\end{array}$ & $\begin{array}{c}\text { Sitrik asit } \\
(\% \mathrm{w} / \mathrm{v})\end{array}$ & $\begin{array}{c}\text { PEG-6000/PEG- } \\
10000 \\
(\% \mathrm{w} / \mathrm{v})\end{array}$ \\
\hline 1 & 0.200 & 0.060 & 0.020 \\
2 & 0.280 & 0.060 & 0.020 \\
3 & 0.200 & 0.090 & 0.020 \\
4 & 0.280 & 0.090 & 0.020 \\
5 & 0.200 & 0.060 & 0.025 \\
6 & 0.280 & 0.060 & 0.025
\end{tabular}

\begin{tabular}{cccc}
7 & 0.200 & 0.090 & 0.025 \\
8 & 0.280 & 0.090 & 0.025 \\
9 & 0.173 & 0.075 & 0.023 \\
10 & 0.307 & 0.075 & 0.023 \\
11 & 0.240 & 0.050 & 0.023 \\
12 & 0.240 & 0.100 & 0.023 \\
13 & 0.240 & 0.075 & 0.018 \\
14 & 0.240 & 0.075 & 0.027 \\
15 & 0.240 & 0.075 & 0.023 \\
16 & 0.240 & 0.075 & 0.023 \\
17 & 0.240 & 0.075 & 0.023 \\
18 & 0.240 & 0.075 & 0.023 \\
19 & 0.240 & 0.075 & 0.023 \\
20 & 0.240 & 0.075 & 0.023 \\
\hline
\end{tabular}

\section{4. Şişme Deneyleri}

Hidrojellerin şişme derecesini incelemek amacıyla, oda sıcaklığında şişme testleri uygulanmıştır. Şişme testlerinde, merkezi kompozit tasarım ile belirlenen deneylerdeki faktörlerin miktarlarına göre hazırlanan polimerler ve farklı gözenek oluşturucu ajan kullanıldığında (PEG-6000/PEG-10000), bu parametre değişikliğinin şişme derecesine etkisi araştırılmıştır. Elde edilen veriler yardımıyla hidrojellerin şişme derecesi, Eşitlik 1 ile hesaplanmıştır.

Hidrojellerin kuru kütleleri, $\pm 0,0001$ duyarlıkta tartım yapan terazide tartılmıștır. Tartılan hidrojeller, içerisinde $50 \mathrm{~mL}$ saf su bulunan beherlere bırakılmıştır. Hidrojellerin çözücülere bırakılma zamanı $\mathrm{t}=0$ dakika olarak alınmıştır. Belirli zaman aralıklarında (10., 20., 30., 45., 60., 70., 80. ve 90. dakika) içinde çözücü bulunan beherlerden alınan hidrojellerin yüzeyindeki su hafifçe kurulandıktan sonra tartılmış ve kütle artışları izlenmiştir. Şişmesi izlenen jel örneklerinde, belli bir süre sonra değişmeyen kütle değerleri görülmüş, jelin denge şişme değerine eriştiği varsayılarak, deney sonlandırılmıştır.

Tasarıma göre, optimum miktarlar belirlendikten sonra üretilen hidrojeller için, saf suda ve farklı pH'lardaki asetik asit-sodyum asetat ( $\mathrm{pH}$ 5,5), sodyum karbonat-sodyum bikarbonat (pH 9,0) tampon çözeltileri ortamında, şişme testleri gerçekleștirilmiştir.

\section{Bulgular}

HPßCD-CMC hidrojel filmleri, çapraz bağlama maddesi olarak sitrik asidin kullanıldığı, çapraz bağlama metodu ile hazırlanmıștır. Hidrojelin sentezlenmesinde yüksek molekül ağırlıklı polietilen glikol [PEG(6000) ve PEG(10000)], gözenek oluşturucu ajan olarak kullanılmıştır. Hidrojelin oluşumu için muhtemel reaksiyon mekanizması, Şekil 1 'de verilmiştir.

Sitrik asit ile çapraz bağlanma, NaCMC ve PEG kullanılarak gerçekleştirilmiştir. Monomer başına, üç 
hidroksil grubu içeren CMC ve PEG, hidroksillenmiş uç gruplara sahiptir. NaCMC veya PEG'in serbest hidroksil grupları ile reaksiyona giren siklik anhidrit ara maddesi, sitrik asidin yüksek sıcaklıklara $\left(80^{\circ} \mathrm{C}\right.$ 'nin üzerine) ısıtılıp, yapıdan suyun uzaklaşması sonucu oluşur. Sitrik anhidrit, NaCMC veya PEG'in bitişik polimer zincirlerinin reaktif $\mathrm{OH}$ gruplarını esterleştirerek, ester çapraz bağlantılarının oluşumuna yol açar. CMC'nin yapısındaki 6 nolu karbona bağlı hidroksil grupları (Anhidroglukoz ünitesinin C6'sına bağlı OH grubu) ve PEG'in uç kısmındaki serbest $\mathrm{OH}$ grupları oldukça reaktiftir ve CMC-PEG hidrojellerini oluşturan sitrik asitle esterifikasyon reaksiyonuna kolaylıkla katılabilir. Bu çalışmada, kullanılan CMC'nin ikame derecesi 0,7'dir. CMC'nin 2 ve 3 nolu karbona bağlı $\mathrm{OH}$ gruplarının esterifikasyon reaksiyonuna katılım olasılı̆̆ yüksektir. Şekil 2'de, CMC-PEG hidrojel filminin oluşumu için muhtemel reaksiyon mekanizması verilmiștir [13].

Demitri ve arkadaşları tarafından gerçekleştirilen çalışmada, sitrik asidin diferansiyel tarama kalorimetrisi (DSC) analizi, sıcaklık $60^{\circ} \mathrm{C}$ 'nin üzerine çlktığında anhidritin oluştuğunu göstermektedir $[11,23]$. Sitrik asidin tamamen bozunması, yaklaşık $160{ }^{\circ} \mathrm{C}$ 'de bașlar. Buna karşıllk, katı NaCMC'un DSC analizi, $100^{\circ} \mathrm{C}$ 'nin üzerinde olası bir bozunma göstermektedir [7]. $\mathrm{Bu}$ nedenle $\mathrm{NaCMC}, 100^{\circ} \mathrm{C}$ 'nin altında termal olarak kararlıdır. Sonuç olarak sentez sıcaklığı, NaCMC tuzunu bozmadan, siklik anhidrit ara maddesini oluşturarak sitrik asit çapraz bağlanmasını sağlamak için $50^{\circ} \mathrm{C}$ ve $80^{\circ} \mathrm{C}$ olarak seçilmiştir. Ancak yapılan denemelerde, $80^{\circ} \mathrm{C}$ 'de hazırlanan hidrojeller çok kısa sürede kuruduğundan, şişme testlerinde bu hidrojeller denge șișme oranına ulaşmadan çok kısa sürede parçalandığı gözlemlenmiştir. Bunun için optimum kurutma sicaklığı $50^{\circ} \mathrm{C}$ olarak belirlenmiştir.

HP $\beta C D-C M C$ hidrojelinin sentezlenmesinde, deneysel değişkenleri optimize ederek veya değiştirerek, maksimum şişme kapasitesine sahip hidrojel hazırlanabilir. Genellikle, hidrojel hazırlanırken çalışmacılar tarafından şişme derecesine etkisi olduğu bilinen parametreler tek tek değiştirilerek, çeşitli kombinasyonlarda elde edilen hidrojellerden en çok şişme değerine sahip olan elde edilmeye çalışılır. Fakat bu yöntem, hem çok zaman kaybettirir hem de hidrojelin oluşturulması için birçok parametrenin etkisi olduğu düşünüldügünde, tam anlamiyla kontrol sağlanamaz. $\mathrm{Bu}$ nedenle bu çalışmada, birden fazla parametrenin tek bir cevap değeri üzerine etkisini değerlendirmemize olanak sağlayan deneysel tasarım metodu olan, merkezi kompozit dizayn tekniği kullanılmıştır.

Materyal ve yöntem kısmında anlatıldığı gibi 20 adet deneysel çalışmaya göre hidrojeller hazırlanmıș, vakum etüvünde kurutulmuş ve belirtilen sürede sabit tartıma getirilmiştir. Şişme derecesi, bu hidrojeller için ayrı ayrı saf su ortamında belirlenmiştir. Her bir hidrojel için 10., 20., 30., 45., 60., 70., 80. ve 90. dakikadaki şişme dereceleri belirlenmiștir. Olușturulan tasarımlarda kullanılan bileşiklerin miktarları ve bu parametrelere göre elde edilmiş cevap değerleri, Tablo 5 ve 6 'da verilmiștir. Elde edilen cevap faktörü (\% şişme derecesi) ve parametreler arasındaki ilişki, Minitab 17 [22] programı ile çözümlenmiştir.

$\mathrm{Bu}$ parametre/parametrelerden etkin olanlar, varyansların homojenliği esas alınarak ANOVA testi ile belirlenmiştir $(\mathrm{p}<0,05)$. Farklı deneysel çalışma altında toplanan orijinal veriler üç değişkenle ve değișkenlerin etkileşimleriyle ilişkilendirilmiş ve matematiksel modeller olușturulmuștur. Matematiksel modeller, istatistiksel bir program Minitab 17 programı kullanılarak tahmin edilmiştir. Böyle bir tasarımda, cevap değişkenleri aşağıdaki denklemle modellenmiștir:

$$
\begin{gathered}
y=b_{0}+b_{1} x_{1}+b_{2} x_{2}+b_{3} x_{3}+b_{12} x_{1} x_{2}+b_{13} x_{1} x_{3} \\
+b_{23} x_{2} x_{3}+b_{11} x_{1}{ }^{2}+b_{22} x_{2}{ }^{2} \\
+b_{33} x_{3}{ }^{2}
\end{gathered}
$$

Burada, $y$ ölçülen yanıtın seviyesi, $b_{0}$ kesim değeri, $b_{1}, b_{2}, b_{3}, b_{12}, b_{13}, b_{23}, b_{11}, b_{22}, b_{33}$ regresyon katsaylarl, $x_{1}, x_{2}, x_{3}$ ana etkiler, $x_{1} x_{2}, x_{1} x_{3}, x_{2} x_{3}$ ana etkiler arasındaki iki yönlü etkileşimlerdir. Verilerin işlenmesi ve cevap faktörü değerleri ile ilgili çok değişkenli regresyonun bağımsız parametrelerle gerçekleştirilmesi için Minitab 17 programı kullanılmıştır. Bu denklemler, faktör alanı içindeki herhangi bir noktada \% şişme değerini tahmin etmeyi sağlar.

Deneyler sonucunda elde edilen cevap değerleri ile gerçekleştirilen çoklu regresyon analizi sonucu elde edilen regresyon denklemiyle tahmin edilen cevap değerleri, Tablo 5 ve Tablo 6'da verilmiștir. Deneysel olarak elde edilen cevap değerleri ve bu değerler arasındaki uyum, Şekil 3'de verilmiştir. Şekil 3'e göre, deneysel cevap değerlerine karşı regresyon denklemiyle teorik olarak hesaplanan cevap değerlerinin grafiğe geçirilmesiyle elde edilen doğrusal fonksiyonun eğiminin 1 , kesim değerinin de 0'a yakınlığı, belirlenen analiz için seçilen dizaynın yeterliliğini ifade etmektedir. 


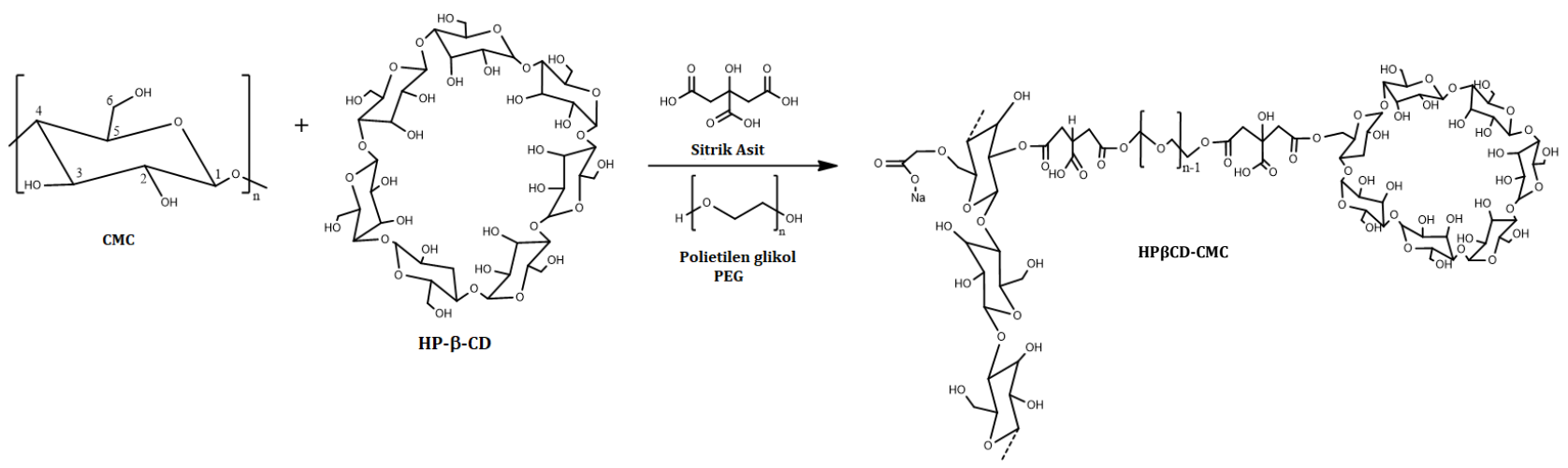

Şekil 1. HPßCD-CMC hidrojelinin sentez reaksiyonu

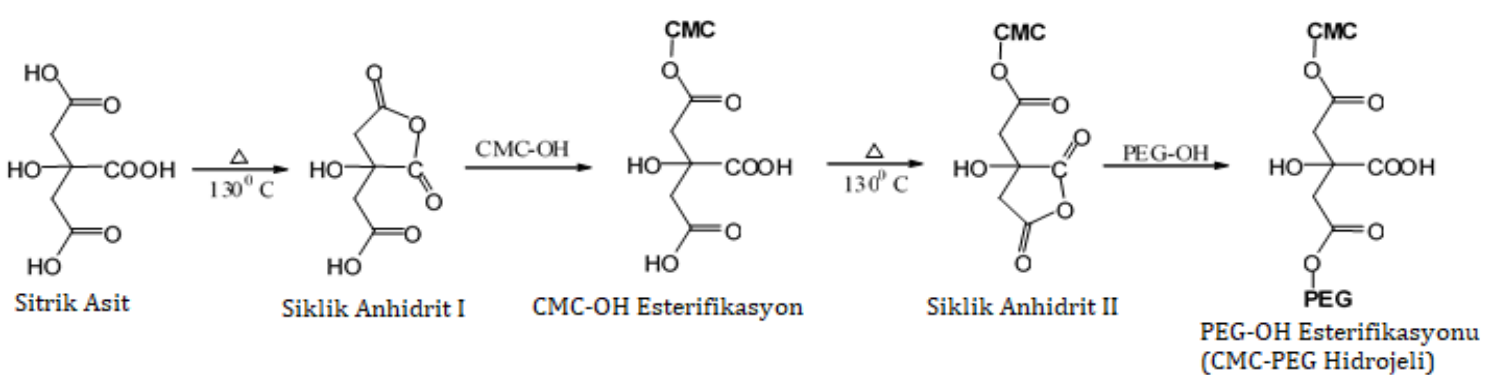

Şekil 2. CMC-PEG hidrojel filmin oluşumunda reaksiyon mekanizması [13]

İlk adımda ana faktör ve ana faktörlerin ikili etkileșimlerinin cevap değeri olarak belirlenen 10., 30., 60. ve 90. dakikalarda, dengedeki \% şişme değerlerini etkileyip etkilemediğini, etkiliyorsa ne ölçüde etkilediğini tespit etmek üzere ikili etkileșimler de deneye dahil edilerek analizler yapılmıştır. Deneyler sonucunda elde edilen cevap değerleri ile çoklu regresyon analizi yapılmıştır. Regresyon analizi PEG-6000 kullanılarak hazırlanan hidrojel için, Tablo 7'de ve PEG-10000 kullanılarak hazırlanan hidrojel için, Tablo 8'de verilmiştir.

Tablolarda belirtilen $\mathrm{p}$ değerleri, \%95 güven seviyesinde, ilgili oldukları parametrenin cevap değerleri üzerine etkisini belirtmektedir. Buna göre $p$ değerlerinin 0,05'den küçük olması parametrenin cevap değerleri üzerindeki etkisinin önemli olduğunu, 0,05'den büyük olması, o parametrenin cevap değeri üzerine etkisinin önemsiz olduğunu ifade etmektedir. Faktör etkilerinin de negatif ya da pozitif olması, ilgili olduğu parametrenin cevap değeri üzerine etkisinin, azaltıcı veya arttırıcı yönde olduğunu ifade etmektedir. Tablolarda belirtilen model uygunsuzluğu (Lack of Fit) değeri, deneysel olarak elde edilen değerler ile regresyon analizi sonucu elde edilen denklemden hesaplanan cevap değerleri arasındaki uygunsuzluğu ifade etmektedir. $\mathrm{Bu}$ değerin 0,05 değerinden küçük olması, deneysel olarak elde edilen değerler ile regresyon denklemi ile hesaplanan değerler arasindaki uyumsuzluğun önemli olduğunu, 0,05 değerinden büyük olması, deneysel olarak elde edilen değerler ile regresyon denklemi ile hesaplanan değerler arasındaki uyumsuzluğun önemsiz olduğunu ifade etmektedir.
Tablolarda verilen p değerleri, faktör etki değerleri ve model uyumsuzluğu değerlerine göre; deneysel tasarımda parametre olarak seçilen NaCMC'nin, sitrik asitin ve PEG-6000/10000'in cevap değeri olarak seçilen şişme değerleri üzerine etkisinin önemli, parametrelerin ikili etkileşimlerinin şişme değeri üzerine etkisinin önemsiz olduğu belirlenmiştir. Ayrıca, model uygunsuzluğu değerinin 0,05 'den büyük olması, merkezi kompozit tasarım aracılığıyla deneysel olarak elde edilen değerler ile çoklu regresyon analizi sonucu elde edilen regresyon denklemiyle tahmin edilen şişme değerleri arasındaki uyumsuzluğun, önemsiz olduğunu ifade etmektedir.

Merkezi kompozit dizaynda birden fazla parametrenin ve deneyin olduğu durumlarda, bu değerlerden optimum koşula karar vermek zaman alıcl ve zor bir iştir. Bu zorluğu aşmak için, istenebilirlik fonksiyonundan (desirability function) faydalanılır. İstenebilirlik fonksiyonu yaklaşımında her bir cevap değeri belirlenen hedeflere göre 0 ile 1 arasında değișen özel bir cevap değerine dönüştürülür (d). Belirlenen hedeflerde, elde edilen değer istenebilirlik fonksiyonunda 1 ile gösterilirken, belirlenen hedeften ne kadar uzaklaşılırsa, istenebilirlik fonksiyonu değeri de 1'den o kadar uzaklaşır. Belirlenen hedefin gerçekleşmesinin imkânsız olduğu durumda, istenebilirlik fonksiyonu 0 değerini alır. Daha sonra, bu d değerlerinden toplam istenebilirlik fonksiyonu elde edilir. Böylece, bütün cevap değerleri tek bir cevap değerine dönüştürülmüş olur. 
Tablo 5. PEG-6000 kullanıldığında belirtilen sürelerde elde edilen deneysel ve parametre seviyeleri kullanılarak hesaplanan \% șişme verileri

\begin{tabular}{|c|c|c|c|c|c|c|c|c|c|c|c|}
\hline \multirow{2}{*}{$\begin{array}{c}\text { Deney } \\
\text { No }\end{array}$} & \multirow{2}{*}{$\begin{array}{l}\text { NaCMC } \\
(\% \mathrm{w} / \mathrm{v})\end{array}$} & \multirow{2}{*}{$\begin{array}{l}\text { Sitrik Asit } \\
(\% \mathrm{w} / \mathrm{v})\end{array}$} & \multirow{2}{*}{$\begin{array}{c}\text { PEG-6000 } \\
(\% \mathrm{w} / \mathrm{v})\end{array}$} & \multicolumn{4}{|c|}{ Deneysel Değerler } & \multicolumn{4}{|c|}{ Teorik Değerler } \\
\hline & & & & 10 dakika & 30 dakika & 60 dakika & 90 dakika & 10 dakika & 30 dakika & 60 dakika & 90 dakika \\
\hline 1 & 0.200 & 0.060 & 0.020 & 82.349 & 183.270 & 137.607 & 153.290 & 83.043 & 183.478 & 138.393 & 153.232 \\
\hline 2 & 0.280 & 0.060 & 0.020 & 103.390 & 235.280 & 185.003 & 166.620 & 102.876 & 234.858 & 194.610 & 166.599 \\
\hline 3 & 0.200 & 0.090 & 0.020 & 96.200 & 198.872 & 198.000 & 194.145 & 95.569 & 198.285 & 207.928 & 193.780 \\
\hline 4 & 0.280 & 0.090 & 0.020 & 117.040 & 267.000 & 289.300 & 242.000 & 116.605 & 266.452 & 299.671 & 241.539 \\
\hline 5 & 0.200 & 0.060 & 0.025 & 46.670 & 126.460 & 114.600 & 103.640 & 47.300 & 127.003 & 124.510 & 103.989 \\
\hline 6 & 0.280 & 0.060 & 0.025 & 48.628 & 110.890 & 103.000 & 97.100 & 49.254 & 111.473 & 113.353 & 97.353 \\
\hline 7 & 0.200 & 0.090 & 0.025 & 96.586 & 221.410 & 188.198 & 172.290 & 97.295 & 221.829 & 198.872 & 172.199 \\
\hline 8 & 0.280 & 0.090 & 0.025 & 100.950 & 223.300 & 223.745 & 200.010 & 100.452 & 223.087 & 233.240 & 199.955 \\
\hline 9 & 0.173 & 0.075 & 0.023 & 64.370 & 172.610 & 148.930 & 151.950 & 63.602 & 172.308 & 158.478 & 151.873 \\
\hline 10 & 0.307 & 0.075 & 0.023 & 82.190 & 216.180 & 215.820 & 186.470 & 82.935 & 216.571 & 226.243 & 186.452 \\
\hline 11 & 0.240 & 0.050 & 0.023 & 69.290 & 152.991 & 109.400 & 106.759 & 68.642 & 152.467 & 119.297 & 106.260 \\
\hline 12 & 0.240 & 0.100 & 0.023 & 121.600 & 258.161 & 260.100 & 226.230 & 122.228 & 258.774 & 270.173 & 226.634 \\
\hline 13 & 0.240 & 0.075 & 0.018 & 108.700 & 227.080 & 222.800 & 207.124 & 109.334 & 227.919 & 232.707 & 207.484 \\
\hline 14 & 0.240 & 0.075 & 0.027 & 66.350 & 144.714 & 146.700 & 131.563 & 65.695 & 143.964 & 156.763 & 131.108 \\
\hline 15 & 0.240 & 0.075 & 0.023 & 67.100 & 187.300 & 248.000 & 205.200 & 66.557 & 187.516 & 247.765 & 204.914 \\
\hline 16 & 0.240 & 0.075 & 0.023 & 66.400 & 188.100 & 248.100 & 204.600 & 66.557 & 187.516 & 247.765 & 204.914 \\
\hline 17 & 0.240 & 0.075 & 0.023 & 66.000 & 187.200 & 247.200 & 205.100 & 66.557 & 187.516 & 247.765 & 204.914 \\
\hline 18 & 0.240 & 0.075 & 0.023 & 67.300 & 188.200 & 247.100 & 204.500 & 66.557 & 187.516 & 247.765 & 204.914 \\
\hline 19 & 0.240 & 0.075 & 0.023 & 67.100 & 187.200 & 248.400 & 205.300 & 66.557 & 187.516 & 247.765 & 204.914 \\
\hline 20 & 0.240 & 0.075 & 0.023 & 66.200 & 188.100 & 247.300 & 205.100 & 66.557 & 187.516 & 247.765 & 204.914 \\
\hline
\end{tabular}


İlkay Konçe vd. / Merkezi Bir Kompozit Tasarım Kullanılarak Karboksimetil Selüloz Temelli Hidrojelin Şişme Oranının Belirlenmesi

Tablo 6. PEG-10000 kullanıldığında belirtilen sürelerde elde edilen deneysel ve parametre seviyeleri kullanılarak hesaplanan \% șişme verileri

\begin{tabular}{|c|c|c|c|c|c|c|c|c|c|c|c|}
\hline \multirow{2}{*}{$\begin{array}{l}\text { Deney } \\
\text { No }\end{array}$} & \multirow{2}{*}{$\begin{array}{c}\mathrm{NaCMC} \\
(\% \mathrm{w} / \mathrm{v})\end{array}$} & \multirow{2}{*}{$\begin{array}{c}\text { Sitrik Asit } \\
(\% \mathrm{w} / \mathrm{v})\end{array}$} & \multirow{2}{*}{$\begin{array}{c}\text { PEG-10000 } \\
(\% \mathrm{w} / \mathrm{v})\end{array}$} & \multicolumn{4}{|c|}{ Deneysel Değerler } & \multicolumn{4}{|c|}{ Teorik değerler } \\
\hline & & & & 10 dakika & 30 dakika & 60 dakika & 90 dakika & 10 dakika & 30 dakika & 60 dakika & 90 dakika \\
\hline 1 & 0.200 & 0.060 & 0.020 & 73.961 & 128.000 & 144.605 & 123.020 & 74.000 & 127.845 & 143.996 & 122.483 \\
\hline 2 & 0.280 & 0.060 & 0.020 & 82.920 & 151.670 & 160.780 & 160.100 & 83.162 & 151.294 & 160.415 & 159.432 \\
\hline 3 & 0.200 & 0.090 & 0.020 & 78.970 & 183.000 & 226.150 & 129.510 & 79.272 & 182.629 & 225.789 & 129.210 \\
\hline 4 & 0.280 & 0.090 & 0.020 & 89.800 & 195.000 & 229.380 & 208.400 & 89.172 & 194.834 & 229.011 & 207.786 \\
\hline 5 & 0.200 & 0.060 & 0.025 & 73.000 & 63.280 & 104.000 & 101.000 & 73.507 & 62.899 & 103.800 & 100.771 \\
\hline 6 & 0.280 & 0.060 & 0.025 & 77.652 & 125.000 & 155.000 & 123.100 & 77.230 & 124.823 & 154.791 & 122.557 \\
\hline 7 & 0.200 & 0.090 & 0.025 & 77.740 & 97.000 & 123.000 & 112.856 & 77.378 & 96.828 & 122.796 & 112.681 \\
\hline 8 & 0.280 & 0.090 & 0.025 & 82.000 & 147.900 & 160.550 & 176.400 & 81.840 & 147.508 & 160.590 & 176.094 \\
\hline 9 & 0.173 & 0.075 & 0.023 & 77.608 & 96.778 & 141.940 & 101.069 & 77.243 & 97.187 & 142.533 & 101.459 \\
\hline 10 & 0.307 & 0.075 & 0.023 & 88.185 & 159.089 & 187.740 & 185.000 & 88.699 & 159.521 & 188.121 & 185.853 \\
\hline 11 & 0.240 & 0.050 & 0.023 & 77.970 & 94.451 & 127.853 & 113.769 & 77.700 & 94.837 & 128.464 & 114.548 \\
\hline 12 & 0.240 & 0.100 & 0.023 & 85.590 & 159.526 & 201.760 & 164.755 & 86.009 & 159.981 & 202.120 & 165.223 \\
\hline 13 & 0.240 & 0.075 & 0.018 & 74.968 & 192.668 & 197.000 & 157.920 & 74.920 & 193.068 & 197.823 & 158.799 \\
\hline 14 & 0.240 & 0.075 & 0.027 & 68.143 & 98.218 & 106.340 & 113.523 & 68.339 & 98.659 & 106.487 & 113.892 \\
\hline 15 & 0.240 & 0.075 & 0.023 & 69.100 & 98.100 & 133.000 & 117.000 & 68.491 & 97.491 & 132.508 & 116.644 \\
\hline 16 & 0.240 & 0.075 & 0.023 & 68.400 & 97.600 & 132.000 & 117.000 & 68.491 & 97.491 & 132.508 & 116.644 \\
\hline 17 & 0.240 & 0.075 & 0.023 & 69.200 & 98.200 & 133.000 & 116.000 & 68.491 & 97.491 & 132.508 & 116.644 \\
\hline 18 & 0.240 & 0.075 & 0.023 & 68.300 & 97.400 & 132.000 & 116.000 & 68.491 & 97.491 & 132.508 & 116.644 \\
\hline 19 & 0.240 & 0.075 & 0.023 & 69.100 & 97.400 & 132.000 & 117.000 & 68.491 & 97.491 & 132.508 & 116.644 \\
\hline 20 & 0.240 & 0.075 & 0.023 & 68.400 & 98.200 & 133.000 & 117.000 & 68.491 & 97.491 & 132.508 & 116.644 \\
\hline
\end{tabular}



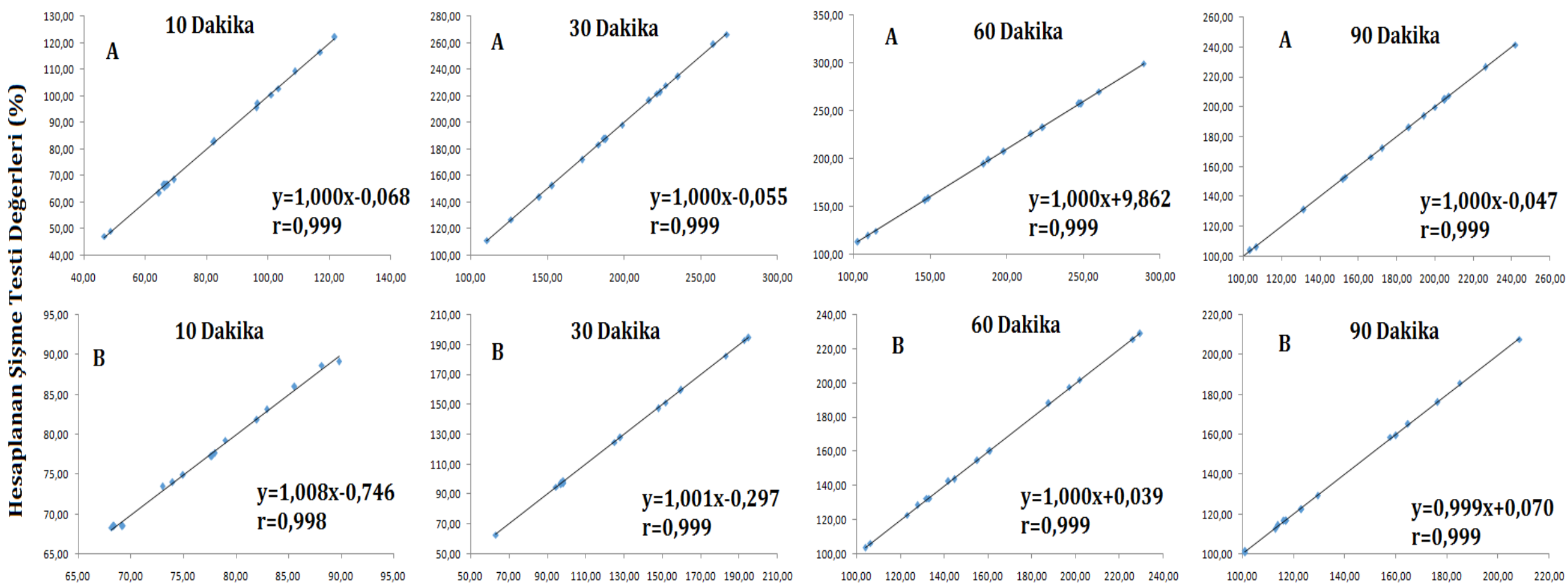

\section{Deneysel Şişme testi Değerleri (\%)}

Şekil 3. Elde edilen regresyon denklemiyle hesaplanan teorik ve deneysel \% şişme değerleri arasındaki ilişki, PEG-6000 (A) ve PEG-10000 (B) kullanılarak hazırlanan hidrojeller 
Tablo 7. PEG-6000 kullanılarak hazırlanan hidrojel için kodlanmış katsayılar ile regresyon analizi sonuçları

\begin{tabular}{|c|c|c|c|c|c|c|c|c|c|c|c|c|}
\hline Faktörler & $\begin{array}{l}\text { Faktör } \\
\text { etkileri }\end{array}$ & 10 dakika & $\mathbf{p}$ & $\begin{array}{l}\text { Faktör } \\
\text { etkileri }\end{array}$ & $\begin{array}{c}30 \\
\text { dakika }\end{array}$ & $\mathbf{p}$ & $\begin{array}{l}\text { Faktör } \\
\text { etkileri }\end{array}$ & $\begin{array}{c}60 \\
\text { dakika }\end{array}$ & $\mathbf{p}$ & $\begin{array}{l}\text { Faktör } \\
\text { etkileri }\end{array}$ & 90 dakika & $\mathbf{p}$ \\
\hline Sabit & & 66.504 & 0.000 & & 137.681 & 0.000 & & 257.689 & 0.000 & & 204.966 & 0.000 \\
\hline Sitrik Asit & 31.854 & 15.927 & 0.005 & 63.200 & 31.600 & 0.002 & 89.695 & 44.848 & 0.000 & 71.571 & 35.786 & 0.003 \\
\hline PEG-6000 & -25.946 & -12.973 & 0.042 & -49.921 & -24.961 & 0.041 & -45.157 & -22.579 & 0.022 & -45.412 & -22.706 & 0.020 \\
\hline NaCMC*NaCMC & 4.747 & 2.373 & 0.190 & 4.771 & 2.385 & 0.823 & -46.248 & -23.124 & 0.022 & -25.280 & -12.640 & 0.125 \\
\hline NaCMC*Sitrik Asit & 0.601 & 0.301 & 0.719 & 8.395 & 4.197 & 0.923 & 22.763 & 11.381 & 0.443 & 17.196 & 8.598 & 0.930 \\
\hline NaCMC*PEG-6000 & -8.940 & -4.470 & 0.342 & -33.454 & -16.727 & 0.154 & -28.687 & -14.344 & 0.152 & -10.001 & -5.001 & 0.529 \\
\hline Sitrik Asit*PEG-60 & 18.734 & 9.367 & 0.293 & 40.010 & 20.005 & 0.146 & 7.413 & 3.707 & 0.674 & 13.831 & 6.916 & 0.475 \\
\hline $\begin{array}{l}\text { Model Uygunsuzluğu } \\
\text { (Lack of Fit) }\end{array}$ & & 0.093 & & & 0.116 & & & 0.365 & & & 0.193 & \\
\hline
\end{tabular}

Tablo 8. PEG-10000 kullanılarak hazırlanan hidrojel için kodlanmış katsayılar ile regresyon analizi sonuçları

\begin{tabular}{|c|c|c|c|c|c|c|c|c|c|c|c|c|}
\hline Faktörler & $\begin{array}{l}\text { Faktör } \\
\text { etkileri }\end{array}$ & 10 dakika & $\mathbf{p}$ & $\begin{array}{l}\text { Faktör } \\
\text { etkileri }\end{array}$ & $\begin{array}{c}30 \\
\text { dakika }\end{array}$ & $\mathbf{p}$ & $\begin{array}{l}\text { Faktör } \\
\text { etkileri }\end{array}$ & $\begin{array}{c}60 \\
\text { dakika }\end{array}$ & $\mathbf{p}$ & $\begin{array}{l}\text { Faktör } \\
\text { etkileri }\end{array}$ & 90 dakika & $\mathbf{p}$ \\
\hline Sabit & & 68.495 & 0.000 & & 97.477 & 0.000 & & 132.474 & 0.000 & & 116.632 & 0.000 \\
\hline Sitrik Asit & 4.949 & 2.474 & 0.020 & 38.719 & 19.360 & 0.025 & 43.786 & 21.893 & 0.006 & 30.123 & 15.062 & 0.041 \\
\hline PEG-10000 & -3.916 & -1.958 & 0.003 & -56.138 & -28.069 & 0.017 & -54.308 & -27.154 & 0.000 & -26.703 & -13.352 & 0.035 \\
\hline NaCMC*NaCMC & 10.239 & 5.119 & 0.333 & 21.824 & 10.912 & 0.203 & 23.205 & 11.603 & 0.202 & 19.102 & 9.551 & 0.224 \\
\hline PEG-10000*PEG 10000 & 2.220 & 1.110 & 0.333 & 34.205 & 17.102 & 0.203 & 13.893 & 6.946 & 0.202 & 13.931 & 6.966 & 0.224 \\
\hline NaCMC*Sitrik Asit & 0.370 & 0.185 & 0.697 & -5.622 & -2.811 & 0.666 & -6.599 & -3.299 & 0.681 & 20.814 & 10.407 & 0.137 \\
\hline NaCMC*PEG-10000 & -2.719 & -1.360 & 0.167 & 19.238 & 9.619 & 0.344 & 17.286 & 8.643 & 0.167 & -7.581 & -3.791 & 0.789 \\
\hline Sitrik Asit*PEG-10000 & -0.700 & -0.350 & 0.873 & -10.428 & -5.214 & 0.595 & -31.399 & -15.699 & 0.019 & 2.592 & 1.296 & 0.835 \\
\hline $\begin{array}{l}\text { Model Uygunsuzluğu } \\
\text { (Lack of Fit) }\end{array}$ & & 0.418 & & & 0.435 & & & 0.284 & & & 0.113 & \\
\hline
\end{tabular}

Bu çalıșmada, belirlenen istenebilirlik fonksiyonunun hedefi, cevap olarak belirlenen şişme değerini maksimum yapan değer olarak belirlenmiștir. Bu hedef doğrultusunda, deneysel tasarımlarda cevap değeri olan 10., 30., 60. ve 90. dakikalardaki şişme derecesi değerleri, d değerine dönüștürülmüștür. Elde edilen veriler, Tablo 9'da verilmiştir.

Buna göre istenebilirlik fonksiyonuyla yapılan değerlendirme neticesinde, hem PEG-6000 hem de PEG-10000'in parametre olarak kullanıldığı deneysel tasarım için 10., 30., 60. ve 90. dakikalardaki şişme derecesi değerlerine göre optimum miktarlar, 0,307 g NaCMC; 0,100 g Sitrik asit ve 0,018 g PEG-6000/PEG10000 olarak belirlenmiştir. Bu polimer çözelti ortamına 0,043 g HPßCD ilave edilmiștir, Ayrıca, elde edilen optimum miktarlar 3D yüzey diyagramlarında da görülmektedir. 3D’ye göre çizilen yüzey diyagramları, Şekil 4 ve Şekil 5'de verilmiştir.

Sabit reaksiyon sıcaklı̆̆ı ve süresi, vakum sınırı değerlerinde hazırlanan PEG-6000 ve PEG-10000 içeren hidrojeller, merkezi kompozit dizayn tasarımına göre belirlenmiş optimum miktarlarda hazırlanmıştır. Hazırlanan hidrojeller, saf suda ve farklı pH'lardaki (pH 5,5; pH 9,0) tampon çözelti ortamlarında, oda sıcaklığında șișme testlerine tabi tutulmuştur, Eşitlik 1 kullanılarak hidrojellerin \% şişme değerleri hesaplanmıştır. $\mathrm{Bu}$ optimum miktarlar kullanarak elde edilen veriler, Şekil 6'da verilmiștir.

Belirlenen optimum miktarlarda PEG 6000 ile hazırlanan hidrojellerin, PEG 10000 de hazırlanan hidrojellere göre, üç farklı miktarda da daha yüksek şişme oranına sahip olduğu görülmektedir. Gözenek oluşturucu ajanın molekül ağırlığı artınca, hidrojellerin suyu absorplama kapasitesinin de artması beklenirken, az da olsa bir düşüş gözlenmiştir. Tüm jellerin yaklaşık olarak 60. dakikada dengeye ulaştıkları, Şekil 6'da görülmektedir. Grafiklerden görüldüğü gibi, PEG 6000 ile PEG 10000 hidrojellerinin saf suda ve asidik ortamda da yapılan deneylerde \% şişme değerleri, birbirine yakındır. PEG 6000/ PEG 10000 ile hazırlanan hidrojellerde, bazik ortamda yapılan şişme testi verileri, saf su ve asidik ortamda yapılan şişme testi verilerine göre, daha yüksektir. Bazik ortamda, moleküller arasındaki hidrojen bağı sayısı azaldığı için, yapının gevşediği ve daha çok şiştiği düşünülmektedir. 
Tablo 9. Cevap değerlerinin istenebilirlik skalasına göre karşılıkları

\begin{tabular}{|c|c|c|c|c|c|c|c|c|c|c|c|}
\hline \multirow{2}{*}{ Deney No } & \multirow{2}{*}{$\begin{array}{l}\mathrm{NaCMC} \\
(\% \mathrm{w} / \mathrm{v})\end{array}$} & \multirow{2}{*}{$\begin{array}{c}\text { Sitrik Asit } \\
(\% \mathrm{w} / \mathrm{v})\end{array}$} & \multirow{2}{*}{$\begin{array}{c}\text { PEG-6000 } \\
(\% \mathrm{w} / \mathrm{v})\end{array}$} & \multicolumn{4}{|c|}{ PEG-6000 } & \multicolumn{4}{|c|}{ PEG-10000 } \\
\hline & & & & $d_{10 . \text { dakika }}$ & $d_{30 . \text { dakika }}$ & $d_{60 . \text { dakika }}$ & $d_{90 . \text { dakika }}$ & $d_{10 . \text { dakika }}$ & $d_{30 . \text { dakika }}$ & $d_{60 . \text { dakika }}$ & $d_{90 . d a k i k a}$ \\
\hline 1 & 0.200 & 0.060 & 0.020 & 0.485 & 0.465 & 0.190 & 0.388 & 0.000 & 0.311 & 0.093 & 0.045 \\
\hline 2 & 0.280 & 0.060 & 0.020 & 0.749 & 0.794 & 0.438 & 0.480 & 0.102 & 0.565 & 0.278 & 0.237 \\
\hline 3 & 0.200 & 0.090 & 0.020 & 0.654 & 0.560 & 0.509 & 0.668 & 0.560 & 0.176 & 0.372 & 0.577 \\
\hline 4 & 0.280 & 0.090 & 0.020 & 0.933 & 0.996 & 0.995 & 0.997 & 0.289 & 0.209 & 0.779 & 0.115 \\
\hline 5 & 0.200 & 0.060 & 0.025 & 0.075 & 0.103 & 0.061 & 0.048 & 0.482 & 0.430 & 0.313 & 0.590 \\
\hline 6 & 0.280 & 0.060 & 0.025 & 0.034 & 0.004 & 0.002 & 0.002 & 0.998 & 0.294 & 0.156 & 0.770 \\
\hline 7 & 0.200 & 0.090 & 0.025 & 0.675 & 0.711 & 0.461 & 0.519 & 0.312 & 0.279 & 0.349 & 0.482 \\
\hline 8 & 0.280 & 0.090 & 0.025 & 0.717 & 0.719 & 0.645 & 0.710 & 0.478 & 0.294 & 0.435 & 0.009 \\
\hline 9 & 0.173 & 0.075 & 0.023 & 0.226 & 0.393 & 0.245 & 0.379 & 0.093 & 0.069 & 0.051 & 0.332 \\
\hline 10 & 0.307 & 0.075 & 0.023 & 0.483 & 0.677 & 0.608 & 0.617 & 0.334 & 0.295 & 0.261 & 0.095 \\
\hline 11 & 0.240 & 0.050 & 0.023 & 0.289 & 0.267 & 0.043 & 0.072 & 0.595 & 0.632 & 0.128 & 0.632 \\
\hline 12 & 0.240 & 0.100 & 0.023 & 0.950 & 0.944 & 0.845 & 0.895 & 0.612 & 0.206 & 0.593 & 0.442 \\
\hline 13 & 0.240 & 0.075 & 0.018 & 0.815 & 0.744 & 0.654 & 0.768 & 0.086 & 0.475 & 0.594 & 0.093 \\
\hline 14 & 0.240 & 0.075 & 0.027 & 0.247 & 0.219 & 0.256 & 0.254 & 0.651 & 0.641 & 0.492 & 0.452 \\
\hline 15 & 0.240 & 0.075 & 0.023 & \multirow{6}{*}{0.267} & \multirow{6}{*}{0.492} & \multirow{6}{*}{0.777} & \multirow{6}{*}{0.744} & \multirow{6}{*}{0.281} & \multirow{6}{*}{0.663} & \multirow{6}{*}{0.493} & \multirow{6}{*}{0.195} \\
\hline 16 & 0.240 & 0.075 & 0.023 & & & & & & & & \\
\hline 17 & 0.240 & 0.075 & 0.023 & & & & & & & & \\
\hline 18 & 0.240 & 0.075 & 0.023 & & & & & & & & \\
\hline 19 & 0.240 & 0.075 & 0.023 & & & & & & & & \\
\hline 20 & 0.240 & 0.075 & 0.023 & & & & & & & & \\
\hline
\end{tabular}




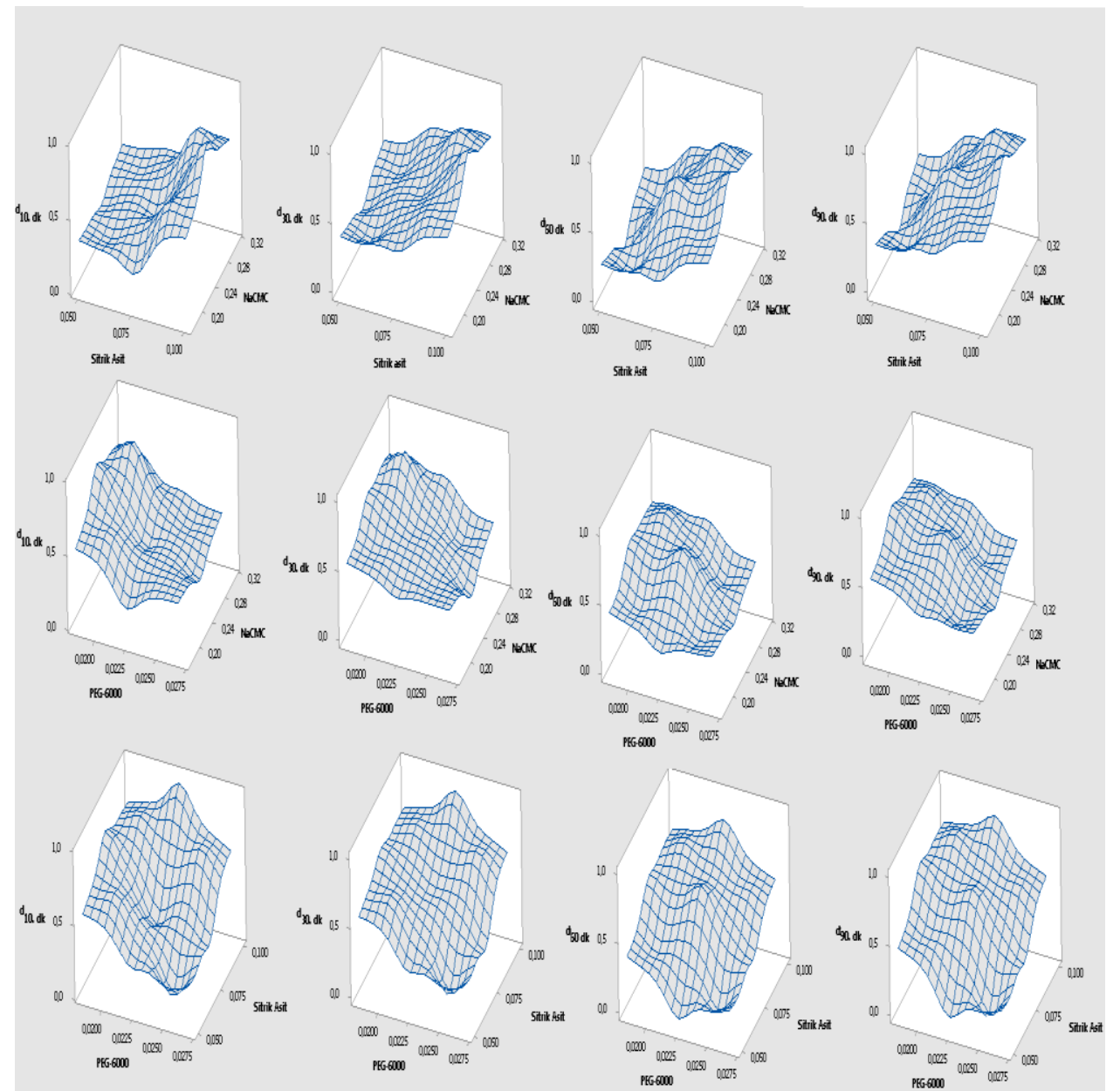

Şekil 4. PEG-6000 kullanılarak hazırlanan hidrojelin 10., 30., 60. ve 90. dakikalardaki şişme değerlerine göre çizilen 3D grafikleri
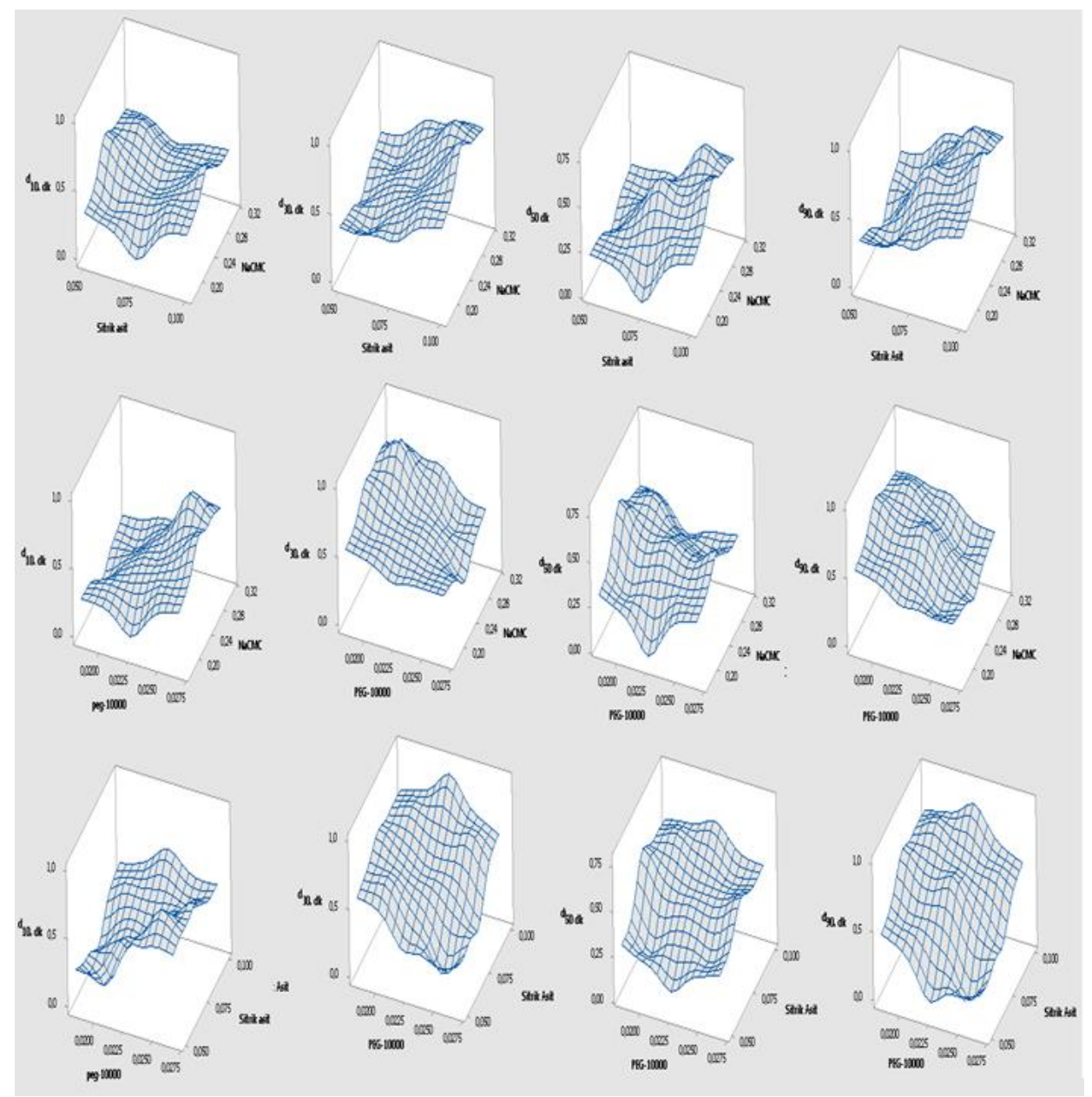

Şekil 5. PEG-10000 kullanılarak hazırlanan hidrojelin 10., 30., 60. ve 90. dakikalardaki şişme değerlerine göre çizilen 3D grafikleri 


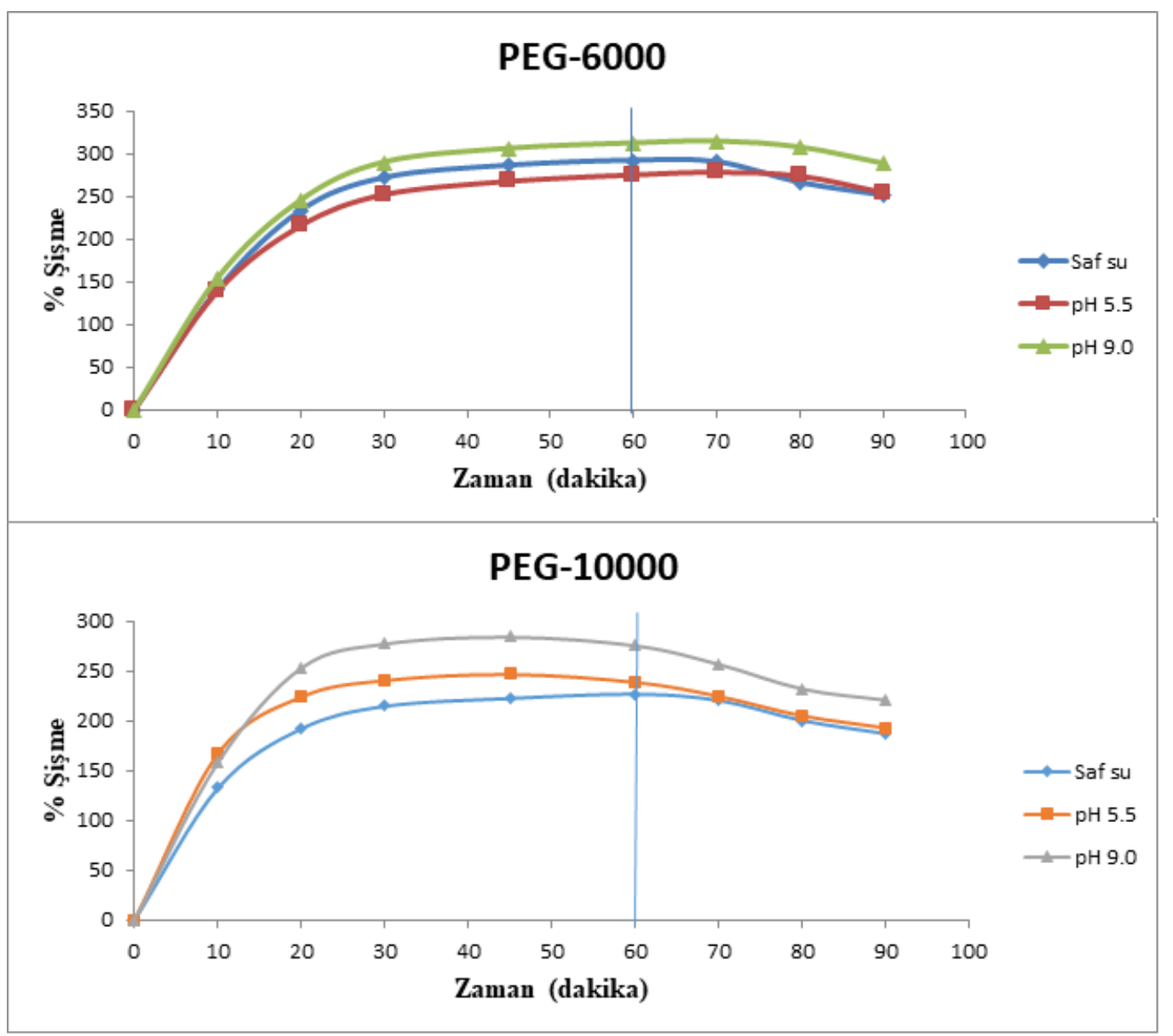

Şekil 6. Optimum miktarlar kullanarak hazırlanan hidrojellerin \% şişme verileri

Optimum miktarlar kullanılarak, PEG 6000 ve PEG 10000 ile hazırlanan HPßCD-CMC hidrojellerin görüntüsü, Şekil 7'de verilmiştir.

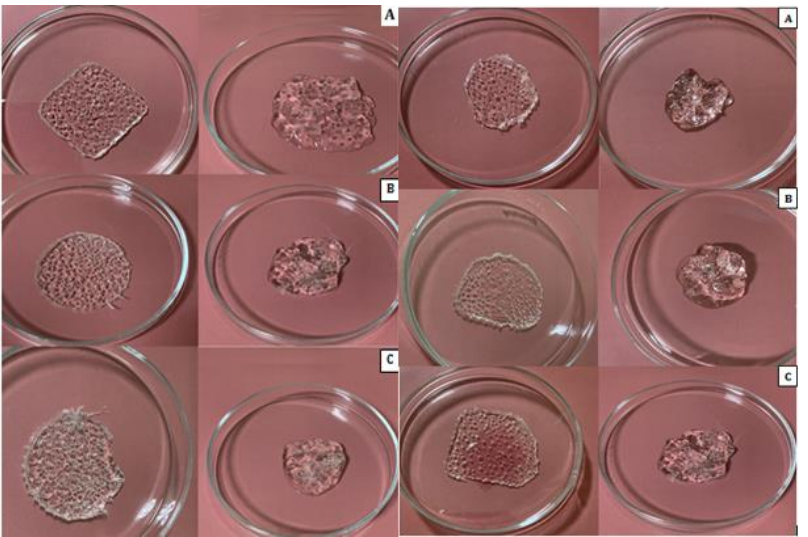

Şekil 7. PEG 6000 ve PEG 10000 ile hazırlanan hidrojellerin görüntüsü (Soldaki kuru jel, sağdaki ıslak jel) A) saf su, B) $\mathrm{pH} \mathrm{5,5,} \mathrm{C)} \mathrm{pH} \mathrm{9,0}$

\section{Tartışma ve Sonuç}

Bu çalışmada, sodyum karboksimetil selüloz, sitrik asit ve polietilen glikol 6000/10000 farklı miktarlarda kullanılarak karboksimetil selüloz temelli hidrojelin sentezlenmesi amaçlanmıştır. Ayrıca, hidrojelin sentezlenmesi sırasında, çözelti ortamına 2- hidroksipropil- $\beta$-siklodekstrinde ilave edilmiştir. $\beta$ siklodekstrin türevi olan bu büyük moleküllü bileşik, sentezlenen hidrojelin etkinliğini ve uygulanabilirliğini arttırmaktadır. Hidrofobik bileşik ve hidrofilik polimerin birbirini dışlaması nedeniyle, bu tür hidrojellere, hidrofobik bileşik yüklemek ve salınımlarını kontrol etmek zordur. $\mathrm{Bu}$ sebeple, hidrofilik olan CMC temelli hidrojellere, hidrofobik bileșiği yüklemeden önce, bu hidrojellerin yapılarında siklodekstrin türevlerinin bulunması tercih edilir. Literatürde, karboksimetil selüloz kullanılarak hazırlanmış hidrojeller bulunmaktadır. $\mathrm{Bu}$ tip hidrojeller farklı metotlarla hazırlandığı için, içerisinde bulunan çapraz bağlayıcı, başlatıcl, gözenek oluşturucularda farklı bileşikler kullanılmaktadır. Capanema ve ark, (2018) tarafindan yapılan çalışmada, NaCMC, sitrik asit ve gözenek oluşturucu olarak da polietilen glikol (Mw: $1521 \mathrm{~g} / \mathrm{mol}$ ) kullanılmıştır [12]. Polimer çözeltisinde kullanılan oranlar, deneme yanılma yöntemiyle bulunmuş ve herhangi bir optimizasyon çalışması yapılmamıștır. Kono ve ark, (2013) tarafından yapılan çalışmada $\beta$ siklodekstrin-karboksimetil selüloz içeren bir hidrojel hazırlanmıştır [24]. Çapraz bağlayıcı olarak, etilen glikol diglisidil eter kullanılmıştır. Bu çalışmada da herhangi bir optimizayon çalıșması bulunmamaktadır. Ghorpade ve ark, (2017) Sitrik asit çapraz bağlı $\beta$ siklodekstrin-karboksimetilselüloz ( $\quad$ (BCD-CMC) hidrojel filmleri hazırlanmıştır. Hazırlanan hidrojele 
suda az çözünen bir bileşik olan, ketokonazol eklenerek bu ilaç etken maddenin kontrollü salınımı belirlenmiștir [13]. Çalışma şartları ve kullanılan kimyasalların miktarları, deneme yanılma metoduyla bulunmuştur. Malik ve arkadaşları (2017) tarafından yapılan çalışmada, ilaç dağıtım sistemlerinin geliştirilmesinde polimerlerin potansiyel rolünü araştırmak için, $\beta$-siklodekstrin, karboksimetil selüloz, akrilik asit ve N'N'-metilenbis-akrilamid kullanılarak sentezlenen hidrojele, suda az çözünen asiklovir yüklenerek bileșiğin kontrollü salınımı sağlanmıștır [25]. Bu çalışmada da herhangi bir optimizasyon işlemi bulunmamaktadır. Sonuç olarak, çalışmamızda sentezlenen hidrojelin, maksimum su emme kapasitesi ile sentezde yer alan faktörlerin ana etkisini ve etkileşim etkisi merkezi kompozit dizayn metodu kullanılarak belirlenmiştir. Yüksek şişme kapasitesine sahip sentezlenen bu hidrojel, hidrofobik bileşiklerin kontrollü salınımı için hazırlanmıştır.

\section{Teșekkür}

$\mathrm{Bu}$ çalışma, Süleyman Demirel Üniversitesi Bilimsel Araştırma Projeleri Koordinasyon Birimi, Isparta, Türkiye'den FDK-2020-8125 nolu proje ile finansal olarak desteklenmiştir.

\section{Etik Beyanı}

Bu çalışmada, "Yükseköğretim Kurumları Bilimsel Araștırma ve Yayın Etiği Yönergesi" kapsamında uyulması gerekli tüm kurallara uyulduğunu, bahsi geçen yönergenin "Bilimsel Araştırma ve Yayın Etiğine Aykırı Eylemler" başlığı altında belirtilen eylemlerden hiçbirinin gerçekleștirilmediğini taahhüt ederiz.

\section{Kaynakça}

[1] Ahmed, E. M. 2015. Hydrogel: Preparation, Characterization, And Applications, Journal of Advanced Research, 6, 105-121.

[2] Maitra, J., Shukla, K. V. 2014. Cross-linking in Hydrogels, American Journal of Polymer Science, $4(2), 25-31$.

[3] Guilherme, M. R., Aouada, F. A., Fajardo, A. R., Martins, A. F., Paulino, A. T., Davi, M. F. T., Rubira, A. F., Muniz, E. C. 2015. Super Absorbent Hydrogels Based On Polysaccharides For Application in Agriculture As Soil Conditioner And Nutrient Carrier: A Review, European Polymer Journal, 72, 365-385.

[4] Olayide, S., Lawal, Y. M., Fukae, R., Nishinari, K. 2011. Microporous Hydrogels Of Cellulose Ether Cross-Linked With Di- Or Polyfunctional Glycidyl Ether Made For The Delivery of Bioactive Substances, Colloid and Polymer Science, 289, 1261-1272.

[5] Sannino, A., Demitri, C., Madaghiele, M. 2009. Biodegradable Cellulose-Based Hydrogels: Design And Applications, Materials, 2(2), 353373.
[6] Bao, Y., Ma, J., Li, N. 2011. Synthesis And Swelling Behaviors of Sodium Carboxymethyl Cellulose-g-Poly(AA-co-AM-co-AMPS)/MMT Superabsorbent Hydrogel, Carbohydrate Polymers, 84 (1), 76-82.

[7] Kono, H. 2014. Characterization And Properties of Carboxymethyl Cellulose Hydrogels Crosslinked by Polyethylene Glycol, Carbohydrate Polymers, 106, 84-93.

[8] Barbucci, R., Magnani, A., Consumi, M. 2000. Swelling Behavior of Carboxymethylcellulose Hydrogels in Relation to Cross-Linking, $\mathrm{pH}$, and Charge Density, Macromolecules, 33(20), 74757480 .

[9] Chen, Y., Cui, G., Dan, N., Huang, Y., Bai, Z., Yang, C., Dan, W. 2019. Preparation And Characterization of Dopamine-Sodium Carboxymethyl Cellulose Hydrogel, SN Applied Sciences, 1, 609-618.

[10] Rimmer, S. 2011. Biomedical Hydrogels: Biochemistry, Manufacture And Medical Applications, Materials. 1st, edition. Woodhead Publishing Limited, Cambridge, UK, 288s.

[11] Demitri, C., Sole, R. D., Scalera, F., Sannino, A., Vasapollo, G., Maffezzoli, A., Nicolais, L. 2008. Novel Superabsorbent Cellulose-Based Hydrogels Crosslinked with Citric Acid. Journal of Applied Polymer Science, 110, 2453-2460.

[12] Capanema, N. S. V., Mansur, A. A. P., de Jesus, A. C., Carvalho, S. M., de Oliveira, L. C., Mansur, H. S. 2018. Super Absorbent Crosslinked Carboxymethyl Cellulose-PEG Hydrogels For Potential Wound Dressing Applications, International Journal of Biological Macromolecules, 106, 1218-1234.

[13] Ghorpade, V. S., Yadav, A. V., Dias, R. J. 2017. Citric Acid Crosslinked BCyclodextrin/Carboxymethylcellulose Hydrogel Films For Controlled Delivery of Poorly Soluble Drugs, Carbohydrate Polymers, 164, 339-348.

[14] Khurma, J. R., Nand, A. V. 2008. Temperature and $\mathrm{pH}$ Sensitive Hydrogels Composed of Chitosan And Poly(Ethyleneglycol), Polymer Bulletin, 59, 805-812.

[15] Thompson, D. O. 1997. Cyclodextrins-Enabling Excipients: Their Present And Future Use in Pharmaceuticals, Critical Reviews ${ }^{\mathrm{TM}}$ in Therapeutic Drug Carrier Systems, 14, 1-104.

[16] Loftsson, T., Brewster, M. E. 1996. Pharmaceutical Applications of Cyclodextrins, I: Drug Solubilization And Stabilization, Journal of Pharmaceutical Sciences, 85, 1017-1025.

[17] Challa, R., Alka, A., Javed, A., Khar, R. K. 2005. Cyclodextrins in Drug Delivery: An Updated Review, An Official Journal of the American 
Association of Pharmaceutical Scientists, 6, 329357.

[18] Peppas, N. A., Mikos, A. G. 1986. Preparation Methods and Structure of Hydrogels, Hydrogels in Medicine and Pharmacy, CRC Press Florida, 1, 1-20.

[19] Ratner, B. D. 1986. Hydrogels in Medicine and Pharmacy, Hydrogels Surfaces, CRC Press Florida, 1, 85-93.

[20] Uyanık, A. ed. 2008. Analitik Kimyacılar için İstatistik ve Kemometri. İlke Yayınevi, Ankara, 312 s.

[21] Lazic, Z. R. 2004. Design of Experiments in Chemical Engineering a Practical Guide. 1st, edition. Wiley-VCH, Weinheim, 620s.

[22] Minitab $17 \quad$ program. 2021. https://www.minitab.com/en- us/products/minitab/ (Erișim Tarihi: 10.03.2021).

[23] Demitri, C. 2013. Potential of Cellulose-Based Super Absorbent Hydrogels as Water Reservoir in Agriculture, International Journal of Polymer Science, 28, 622-625.

[24] Kono, H., Onishi, K., Nakamura, T. 2013. Characterization and Bisphenol A Adsorption Capacity of $\quad \beta$-CyclodextrinCarboxymethylcellulose-Based Hydrogels, Carbohydrate Polymers, 98, 784-792.

[25] Malik, N. S., Ahmad, M., Minhas, M. U. 2017. Cross-Linked B-Cyclodextrin And Carboxymethyl Cellulose Hydrogels For Controlled Drug Delivery Of Acyclovir, Plos One, 12(2), 1-17. 